\title{
Country Image Perception on Tertiary Education: A Pilot Study
}

\author{
Lianti Raharjo \\ BINUS International \\ E-Mail: lraharjo@binus.edu
}

\begin{abstract}
To be competitive in this global economy, studying overseas to enhance knowledge and skills is crucial. In fact, choosing which country to go to pursue a degree overseas is a major question for prospective students. Being part of the service industry and being abroad makes overseas higher education difficult to evaluate. This study was designed to analyze how students perceive higher education in ten different countries based on the concept of country image. Further, this study involved early semester students at one international university in Jakarta where they attended school abroad during their last semester. The perceptions of country image from these prospective students will be presented. While the sample was relatively small, the findings can be useful input into developing marketing plans to approach prospective students in Indonesia.
\end{abstract}

Keywords: Country Image, Tertiary Education, Jakarta

\section{INTRODUCTION}

One global impact is the challenge for graduates to compete in the global market, which requires competency and skills at an international level. Therefore, many students, worldwide, are pursuing degrees overseas to broaden their cultural and intellectual horizons. According to a UNESCO press release in 2009, more than 2.8 million students were enrolled in higher educational institutions outside their country of origin in 2007, which was a 53\% increase since 1999. Additionally, the top ten countries with students studying abroad in 2009, included China, India, the Republic of South Korea, Germany, Japan, France, the United States, Malaysia, Canada, and the Russian Federation. These 10 countries represented $37.5 \%$ of the total number of students studying outside of their home countries. 
To remain competitive in the global education market, educational institutions should understand consumer behavior. According to Ozretic-Dosen, Skare, and Krupta (2008), internationalization in many different industries is influenced by country image that is created in the minds of customers, including in education. Further, the role of country image is more important for high-involvement products compared to low-involvement products (Srikantanyoo and Gnoth, 2002). Tertiary education is a part of a service and is a high involvement product because it is difficult to evaluate the quality of prospective students, especially students who intend on studying outside of their country of origin.

The objective of this paper was to analyze the perception of potential mobile Indonesian students toward 10 different country images as it related to tertiary education. The concept of country image and its impact on tertiary education will be described; thereafter, the results of this study will be discussed and implications and limitations of this study will be identified.

\section{LITERATURE REVIEW}

Country image is commonly recognized by different terms such as country of origin, product-country image, country equity, or made-in country image (Kleppe, Iversen and Stensaker, 2002). According to Kleppe, Iversen and Stensaker (2002), country image and country equity are at the national level, while product-country image and country of origin refer to the product level. The determination of country of origin is the country image that is identified toward a certain product or brand (Ahmed, Johnson, and Lim, 2004). Nagashima (1970, cited in Sohail, 2005) concluded that country of origin is defined as a consumer's association with a given country of origin as the picture, reputation, and stereotype that businesspeople and consumers attach to products of that specific country. Meanwhile, country image is defined as the total of all descriptive, inferential, and informational beliefs about a certain country (Martin and Eroglu, 1993 as cited in Zeugner-Roth, Diamantopoulos, and Montesinos, 2008). Finally, Ayyildiz and Cengiz (2007) defined country image as "country of origin effects."

Tertiary education is a part of a service industry that has experienced high contact service with intangible results. Specifically, tertiary education is categorized as a high involvement service (Srikatanyoo and Gnoth, 2002), as prospective students will find it difficult to assess the quality of education and, in a way, will be exposed largely to the service elements (tertiary education elements) and must be actively involved with the education provider for a certain period of time. In the case of 
international tertiary education, an evaluation of education quality is more difficult. Tangible aspects, such as facilities and equipment, might help prospective students assess the quality of education; however, most of time, when intrinsic cues (e.g., taste, performance, and design) are difficult to assess, consumers will rely on extrinsic cues (e.g., brand, country of origin, and price) in their decision-making process (Jacoby et al., 1997, cited in Ahmed et al., 2004). According to Wall and Liefield (1991), many studies have shown that country image is an important extrinsic cue in consumers' perceptions and evaluations of product and service quality compared to other variables.

As a pre-purchasing evaluation of tertiary education for prospective students from overseas is considered difficult, such students primarily use country image as the evaluation cue. Moreover, the quality of an institution is also perceived via country image (Srikantanyoo and Gnoth, 2002). Based on Srikantanyoo and Gnooth's (2002) argument, it can be concluded that prospective students will consider various aspects that are related to studying overseas in relation with the country image variable, such as the reputation of education, climate, distance, cost of living, culture, educational services, educational facilities, programs offered, research quality, and visa and admission requirements.

\section{METHODOLOGY}

The current study was conducted at BINUS International, Jakarta, Indonesia, where data was collected from 50 students during their first semester in the International Business program at BINUS International. Ten countries were chosen for this study, namely Australia, China, France, Germany, the Netherlands, Japan, South Korea, New Zealand, the UK, and the U.S. These countries were chosen simply because of the existing and potential collaboration between BINUS and various universities in several countries.

For the operational variables used in this study, please refer to Cubillo, Sanchez, and Cervino (2006). In sum, these variables included worldwide educational recognition, ease in the immigration process, low cost of living, ease of adapting to the culture, ease of getting a work permit, ease of getting PR (permanent residence), close proximity, ease of university admission, wide selection of courses, lower tuition fees, availability of financial aid, internship availability, large number of international students, top quality educational services, top quality research, and top quality educational facilities. 
The hypotheses formed for this study are as follows:

$\mathrm{H}_{0}$ : A set of association toward tertiary education in a certain country will be perceived similarly by prospective students in Indonesia.

$\mathrm{H}_{\mathrm{a}}$ : A set of association toward tertiary education in a certain country will be perceived differently by prospective students in Indonesia.

\section{RESULTS AND DISCUSSION}

A convenience sample of 50 first-semester students in the International Business program was gathered using a class-based intercept study with only 37 valid questionnaires. All variables used in the questionnaire were tested for reliability using the Spearman-Brown method to check the correlation between the two halves of the variables. The test showed that all variables are reliable.

The Q Cochran test was used to examine the hypotheses at a 95\% confidence limit. The results yielded that Indonesian students had different perceptions toward tertiary education in ten different countries based on the 16 variables above. The $\mathrm{Q}$ Cochran test results are described as follows:

Table 1 Q Cochran test results

\begin{tabular}{|c|c|c|c|}
\hline Country & $\mathrm{Q}$ value & $X^{2}$ value & Significant Variables \\
\hline Australia & 5.294 & $(0.005 ; 5) 11.070$ & $\begin{array}{l}\text { - Worldwide educational recognition } \\
\text { - } \text { - } \text { Avide selection of courses } \\
\text { - } \quad \text { Large number of international students } \\
\text { - } \quad \text { Top quality educational services } \\
\text { - Top quality educational facilities }\end{array}$ \\
\hline China & 19.233 & $(0.005 ; 15) 24.996$ & $\begin{array}{l}\text { - } \text { Worldwide educational recognition } \\
\text { - } \text { Ease of immigration process } \\
\text { - } \text { Ease of adapting to culture } \\
\text { - } \text { Ease of getting a work permit } \\
\text { - } \text { Ease of getting PR } \\
\text { - } \text { Close proximity } \\
\text { - } \text { Ease of university admission } \\
\text { - Wide selection of courses } \\
\text { - Lower tuition fee } \\
\text { - Availability of financial aid }\end{array}$ \\
\hline
\end{tabular}




\section{Table 1 Q Cochran test results (Continued)}

\begin{tabular}{|c|c|c|c|}
\hline Country & $\mathrm{Q}$ value & $\mathrm{X} 2$ value & Significant Variables \\
\hline China & 19.233 & $(0.005 ; 15) 24.996$ & $\begin{array}{l}\text { - Internship availability } \\
\text { - Large number of international students } \\
\text { - Top quality educational services } \\
\text { - Top quality research } \\
\text { - Top quality educational facilities }\end{array}$ \\
\hline France & 8.321 & $(0.005 ; 8) 15.507$ & $\begin{array}{l}\text { - Worldwide educational recognition } \\
\text { - Wide selection of courses } \\
\text { - Lower tuition fee } \\
\text { - Availability of financial aid } \\
\text { - Internship availability } \\
\text { - Large number of international students } \\
\text { - Top quality educational services } \\
\text { - Top quality research } \\
\text { - Top quality educational facilities }\end{array}$ \\
\hline Germany & 11.348 & $(0.005 ; 7) 14.067$ & $\begin{array}{l}\text { - Worldwide educational recognition } \\
\text { - Wide selection of courses } \\
\text { - Availability of financial aid } \\
\text { - Internship availability } \\
\text { - Large number of international students } \\
\text { - Top quality educational services } \\
\text { - Top quality research } \\
\text { - Top quality educational facilities }\end{array}$ \\
\hline $\begin{array}{l}\text { The } \\
\text { Netherlands }\end{array}$ & 11.311 & $(0.005 ; 7) 14.067$ & $\begin{array}{l}\text { - Worldwide educational recognition } \\
\text { - Wide selection of courses } \\
\text { - Availability of financial aid } \\
\text { - Internship availability } \\
\text { - Large number of international students } \\
\text { - Top quality educational services } \\
\text { - Top quality research } \\
\text { - Top quality educational facilities }\end{array}$ \\
\hline Japan & 11.505 & $(0.005 ; 6) 12.592$ & $\begin{array}{l}\text { - Worldwide educational recognition } \\
\text { - Wide selection of courses } \\
\text { - Availability of financial aid } \\
\text { - Internship availability }\end{array}$ \\
\hline
\end{tabular}




\section{Table 1 Q Cochran test results (Continued)}

\begin{tabular}{|c|c|c|c|}
\hline Country & $Q$ value & X2 value & Significant Variables \\
\hline Japan & 11.505 & $(0.005 ; 6) 12.592$ & $\begin{array}{l}\text { - } \quad \text { Top quality educational services } \\
\text { - } \quad \text { Top quality research } \\
\text { - } \quad \text { Top quality educational facilities }\end{array}$ \\
\hline South Korea & 20.020 & $(0.005 ; 13) 22.362$ & $\begin{array}{l}\text { - Worldwide educational recognition } \\
\text { - } \text { Ease of immigration process } \\
\text { - Low living costs } \\
\text { - } \text { Ease of getting a working permit } \\
\text { - } \text { Ease of getting PR } \\
\text { - Close proximity } \\
\text { - } \text { Ease of university admission } \\
\text { - Wide selection of courses } \\
\text { - Lower tuition fee } \\
\text { - Availability of financial aid } \\
\text { - } \text { Internship availability } \\
\text { - Top quality educational services } \\
\text { - Top quality research } \\
\text { - Top quality educational facilities }\end{array}$ \\
\hline $\begin{array}{c}\text { New } \\
\text { Zealand }\end{array}$ & 18.895 & $(0.005 ; 13) 22.362$ & $\begin{array}{l}\text { - } \text { Worldwide educational recognition } \\
\text { - } \text { Ease of immigration process } \\
\text { - } \text { Ease of adapting to culture } \\
\text { - } \text { Ease of getting a work permit } \\
\text { - } \text { Ease of getting PR } \\
\text { - Close proximity } \\
\text { - } \text { Ease of university admission } \\
\text { - Wide selection of courses } \\
\text { - } \text { Availability of financial aid } \\
\text { - Internship availability } \\
\text { - Large number of international students } \\
\text { - Top quality educational services } \\
\text { - Top quality research } \\
\text { - Top quality educational facilities }\end{array}$ \\
\hline
\end{tabular}


Table 1 Q Cochran test results (Continued)

\begin{tabular}{|c|c|c|c|}
\hline Country & $\mathrm{Q}$ value & $\mathrm{X} 2$ value & Significant Variables \\
\hline $\begin{array}{l}\text { The United } \\
\text { Kingdom }\end{array}$ & 6.889 & $(0.005 ; 6) 12.592$ & $\begin{array}{l}\text { - Worldwide educational recognition } \\
\text { - Wide selection of courses } \\
\text { - Availability of financial aid } \\
\text { - Large number of international students } \\
\text { - Top quality educational services } \\
\text { - Top quality research } \\
\text { - Top quality educational facilities }\end{array}$ \\
\hline The USA & 5.556 & $(0.005 ; 5) 11.070$ & $\begin{array}{l}\text { - Worldwide educational recognition } \\
\text { - Availability of financial aid } \\
\text { - Large number of international students } \\
\text { - Top quality educational services } \\
\text { - Top quality research } \\
\text { - Top quality educational facilities }\end{array}$ \\
\hline
\end{tabular}

These results indicate that the respondents perceived the ten countries as having worldwide educational recognition, top quality educational services, and top quality educational facilities. All countries, except the USA, were considered to provide a wide selection of courses. Additionally, all countries, except Australia, were believed to have top quality research. Respondents perceived China as having all the variables used in this study. Further, respondents deemed South Korea and New Zealand as having 14 variables examined in this study. Meanwhile, respondents regarded only six variables for both Australia and the USA. In conclusion, each country yielded different sets of association as perceived by the respondents.

\section{LIMITATIONS OF STUDY AND CONCLUSION}

Some limitations of this study should be mentioned. First, this study was conducted in Indonesia with a small number of respondents from BINUS International University; therefore, the results cannot be generalized. Second, the country image variables that were applied in this study covered all aspects from the country situation to institution and program condition, while the institutions, in their respective countries, may have differences in terms of quality, facilities, services, etc. Third, while all variables in the questionnaire were reliable, the validity of variables used in the questionnaire was not tested.

Despite the limitations noted above, this study demonstrates that prospective 
students have different perceptions toward tertiary education in different countries. This study also shows that country image affects the perception of prospective students in Indonesia and definitely influences the educational field.

\section{REFERENCES}

Ahmed, Z., Johnson, J., and Lim, C. B. (2004). Does country of origin matter for low involvement products? International Marketing Review, 21(1), 102-120.

Ayyildiz, H., and Cengiz, E. (2007). Country image effect on customer loyalty model. Innovative Marketing, 3(2), 42-60.

Cubillo, J. M., Sanchez, J., and Cervino, J. (2006). International students' decision making process. The International Journal of Educational Management, 20(2), 101-114.

Kleppe, I. A., Iversen, N. M., and Stensaker, I. G. (2002). Country image in marketing strategies: Conceptual issues and an empirical Asian illustration. Journal of Brand Management, 10(1), 61-74.

Ozretic-Dosen, D., Skare, V., and Krupka, Z. (2008). The overall image of Slovenia among Croatian students of business and economics. Nase Gospodarstvo, 54(5/6), 95-102.

Sohail, M. (2005). Malaysian consumers' evaluation of products made in Germany: The country of origin effect. Asia Pacific Journal of Marketing and Logistics, 17(1), 89-106.

Srikatanyoo, N., and Gnoth, J. (2002). Country image and international tertiary education. Journal of Brand Management, 10(2), 139-147.

UNESCO. (2009). Global education digest 2009: Comparing education statistics across the world. Retrieved June 19, 2010, from http://www.uis.unesco.org/template/pdf/ged/2009/GED_2009_EN.pdf

Wall, M., and Liefield, J. (1991). Impact of country-of-origin cues on consumer judgments in multi-cue situations: A covariance analysis. Journal of the Academy of Marketing Science, 19(2), 105-113.

Zeugner-Roth, K. P., Diamantopoulos, A., and Montensinos, M. A. (2008). Home country image, country brand equity and consumer's product preferences: An empirical study. Management International Review, 48(5), 577-602. 